\title{
Asistensi Praktikum Fisika dan Pendampingan Fun Science Project Bagi Peserta Didik di SMA Negeri 9 Purworejo
}

\author{
Eko Setyadi Kurniawan ${ }^{1 *}$, Umi Pratiwi ${ }^{2}$, Siska Desy Fatmaryanti ${ }^{3}$ \\ Program Studi Pendidikan Fisika, FKIP, Universitas Muhammadiyah Purworejo \\ Jl. KHA. Dahlan 3 Purworejo, Jawa Tengah, Indonesia \\ *email korespondensi: ekosetyadik@umpwr.ac.id
}

\begin{abstract}
Abstrak - Kemampuan pemahaman konsep dan analisis fisika pada peserta didik dapat didukung dengan kegiatan praktikum di laboratorium, sehingga keterampilan kinerja di laboratorium peserta didik dapat ditingkatkan. Sejalan dengan tujuan tersebut kompetensi pedagogis dan sosial mahasiswa sebagai seorang calon guru Fisika perlu diasah melalui interaksi dengan peserta didik secara langsung di sekolah, salah satunya melalui kegiatan Asistensi. Kegiatan asistensi ini dilaksanakan di sekolah negeri maupun sekolah swasata di kabupaten Purworejo, salah satunya SMA Negeri 9 Purworejo. Materi yang disajikan adalah parktikum mekanika untuk fisika SMA kelas X, fun science project berupa perancangan dan peluncuran roket air, dan kegiatan pengamatan benda langit menggunakan teleskop. Kegiatan dilaksankan mengunakan metode eksperimen di laboratorium, diskusi interaktif, workshop roket air, dan kegiatan hands-on peserta didik dalam pengamatan sun spot. Kegiatan dikemas secara interaktif sehingga peserta didik berperan secara aktif dan mandiri sehingga tercipta suasana pembelajaran di luar kelas yang menyenangkan.
\end{abstract}

Kata kunci: Asistensi, Praktikum fisika, Fun science project

\section{Physics Experiment Assistant and Fun Science Project for Student in SMA Negeri 9 Purworejo}

\begin{abstract}
The ability to understand physics concepts and analyze in learning physics students can be supported by experiment activities in the laboratory, so that performance skills in students' laboratories can be improved. In line with these objectives, the pedagogical and social competences of students as prospective physics teachers need to be improved through direct interaction with students at school, one of which is through assistance activities. This assistance activity is carried out in public schools and private schools in the Purworejo district, one of which is SMA Negeri 9 Purworejo. The material presented is mechanics practice for class X high school physics, fun science projects in the form of designing and launching water rockets, and observing celestial bodies using telescopes. Activities are carried out using experimental methods in the laboratory, interactive discussions, water rocket workshops, and hands-on activities of students in observing sunspots. Activities are packaged interactively so that students play an active and independent role so as to create a pleasant learning atmosphere outside the classroom.
\end{abstract}

Keywords: Assistance, Physics experiment, Fun science project

Article Info: Submitted: 05/02/2019 | Revised: 20/03/2019 | Accepted: 29/03/2019 


\section{PENDAHULUAN}

Pembelajaran fisika tidak dapat dipisahkan dari penguasaan konsep, analisis, dan keterampilan psikomotorik pada peserta didik. Melalui pembelajaran yang inovatif dan menyenangkan diharapkan dapat memberikan pemahaman konsep, penguasaan analisis, dan peningkatan keterampilan/ psikomotorik peserta didik dalam pembelajaran fisika. Menurut (G. D. S. Rahayu \& Firmansyah, 2019; P. Rahayu dkk., 2012), proses pembelajaran tersebut harus memperhatikan keberagaman gaya belajar (learning style) masing-masing peserta didik, sehingga beragam model, metode, maupun strategi belajar dapat divariasikan berdasarkan kebutuhan peserta didik. (Wattimena dkk., 2014) mengemukakan melalui pembelajaran yang aktif di laboratorium dapat meningkatkan kreativitas peserta didik. Senada dengan hal tersebut, (Fidiana dkk., 2012; Kurnianto \& Dwijanant, 2010; Kurniawan \& Ngazizah, 2017) menyebutkan bahwa melalui kegiatan praktikum fisika sederhana kemampuan menyimpulkan dan mengkomunikasikan konsen fisika dapat ditingkatkan dengan lebih baik.

Kegiatan asistensi merupakan serangkaian tugas mata kuliah Asistensi bagi mahasiswa program studi pendidikan fisika semester 4 dan 5. Kegiatan asistensi meliputi tata kelola laboratorium dan pendampingan praktikum fisika di sekolah (Irwanto, 2016). Menurut (Marwoto, 2010) pengalaman mengampu praktikum bagi peserta didik di sekolah oleh mahasiswa merupakan hal yang sangat berharga dalam meningkatkan kemampuan (kompetensi) profesional sebagai calon guru fisika, dan diharapkan dapat memberikan solusi dari permasalahan yang dihadapi pada pembelajaran fisika di kelas. Senada dengan hal tersebut, (Rediarta dkk., 2014; Sudargo, 2010) mengungkapkan bahwa kemampuan berpikir kritis dan dan keterampilan proses siswa dalam pembelajaran didukung oleh kegiatan praktikum sehingga dapat pula meningkatkan kemampuan pedagogik mahasiswa sebagai calon guru. Asistensi perlu ditinjau tingkat efektivitas pelaksanaannya mengingat pelaksanaan kegiatan ini melibatkan siswa, mahasiswa, dan pihak sekolah (Suwardi, 2016). Kemampuan penguasaan alat peraga penting dan keterampilan guru dalam mengelola laboratorium sangat penting untuk menunjang kompetensi dan inovasi pembelajaran IPA di sekolah (Kurniawan \& Ngazizah, 2017)

Hasil observasi dan wawancara kepada guru fisika, diperoleh informasi bahwa praktikum fisika jarang dilaksanakan karena alokasi waktu pembelajaran fisika yang relatif sedikit, ketersediaan alat yang kurang memadai, serta pemahaman peserta didik terhadap materi pembelajaran yang perlu ditingkatkan melalui pembelajaran di kelas. Hal tersebut menjadi dasar dan alasan perlunya kegiatan asistensi di sekolah.

Berdasarkan paparan di atas, tujuan dari kegiatan pengabdian kepada masyarkat di SMA Negeri 9 Purworejo untuk memberikan pendampingan kegiatan praktikum fisika SMA kelas $\mathrm{X}$ yang dilaksanakan di luar jam pelajaran efektif, sehingga diharapkan dapat meningkatkan pemahaman peserta didik dalam penguasaan konsep maupun analisis materi fisika SMA kelas $X$, selain itu memberikan nuansa menyenangkan bagi peserta didik dalam belajar fisika melalui fun science project berupa pembuatan roket air dan pengamatan bintik hitam matahari. 


\section{METODE}

Berdasarkan uraian masalah yang dihadapi, maka dilakukan langkah-langkah kegiatan berupa asistensi praktikum fisika kelas X yang meliputi pengukuran, GLB dan GLBB, penentuan gravitasi bumi menggunakan ayunan matematis yang dipandu oleh mahasiswa; sedangkan kegiatan fun science project merancang roket air dan pengamatan bintik hitam matahari oleh dosen dan mahasiswa. Diagram alir proses pelaksanaan kegiatan disajikan pada Gambar 1 meliputi tahapan input, proses, output, dan outcome..

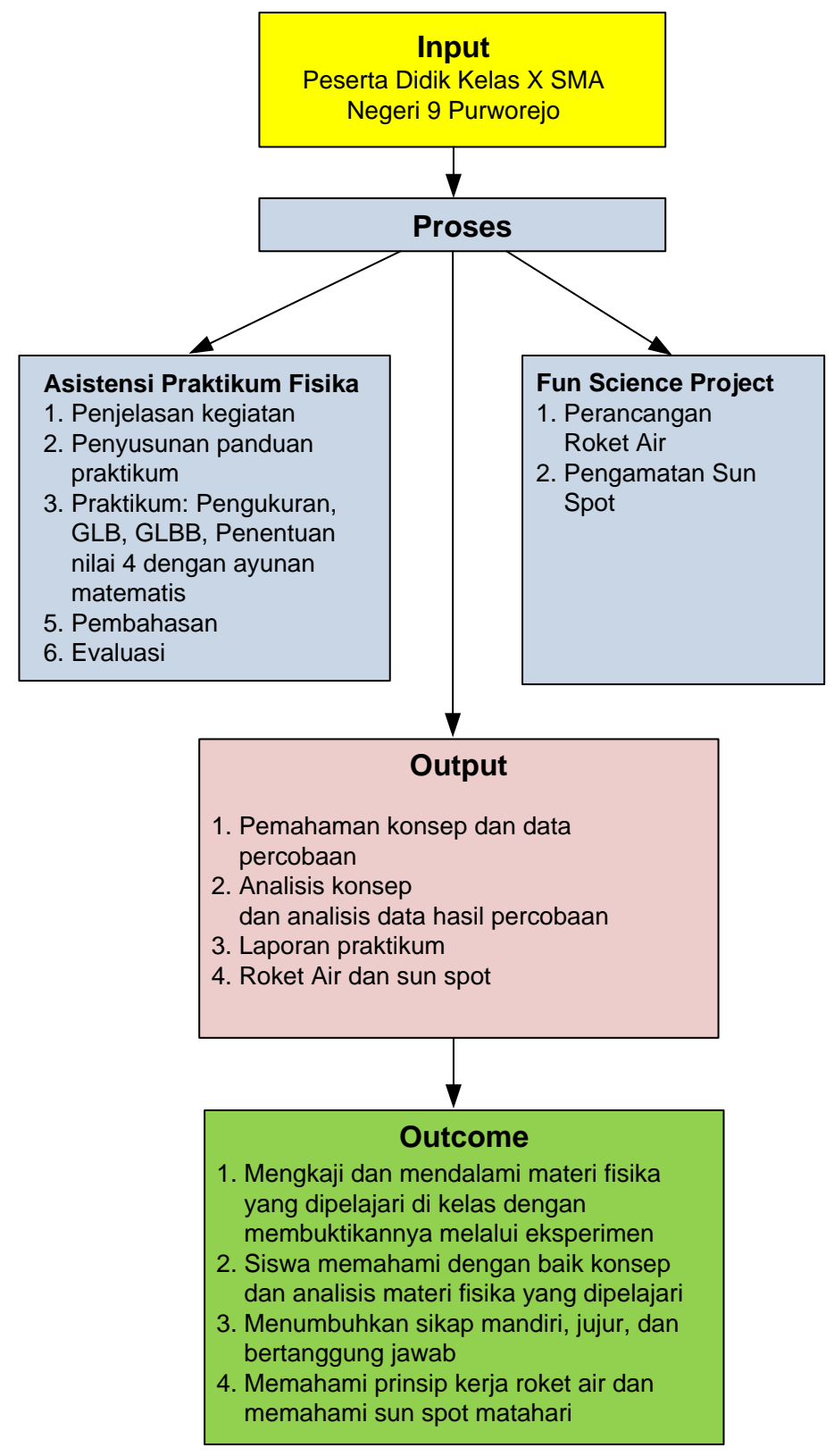

Gambar 1. Alur Kegiatan Pengabdian 
Alur kegiatan pengabdian kepada masyarakat seperti tersaji pada Gambar 1. Tahapan pertama disebut tahapan input pelaksanaan kegiatan yang melibatkan peserta didik kelas $\mathrm{X}$ MIPA-1 dan X MIPA 2 SMA Negeri 9 Purworejo. Tahap kedua adalah proses yang meliputi jenis kegiatan dan rincian kegiatan yang hendak dilaksanakan dalam pengabdian kepada masyarakat. Tahap ketiga adalah output/ hasil berupa pemahaman konsep, analisis hasil percobaan. Tahap outcome/ luaran adalah pemahaman materi dan memiliki kinerja laboratorium yang baik.

\section{Kegiatan dan Pelaksanaan}

Kegiatan dan pelaksanaan pengabdian kepada masyarakat ini terintegrasi dengan kegiatan asistensi praktikum fisika bagi peserta didik di SMA terintegrasi dengan mata kuliah Asistensi I dan Asistensi II bagi mahasiswa semester IV dan V Program Studi Pendidikan Fisika. Sebagai mitra adalah SMA Negeri 9 Purworejo, sedangkan subjek kegiatan asistensi praktikum fisika adalah seluruh peserta didik kelas X MIPA-1 dan X MIPA-2 SMA Negeri 9 Purworejo yang berjumlah 64 peserta didik, yang dilaksanakan dalam 2 hari yaitu tanggal 10 sampai dengan 12 Desember 2018 mulai pukul 08.00 hingga selesai bertempat di laboratorium IPA dan halaman SMA Negeri 9 Purworejo.

\section{Prosedur Kegiatan}

Prosedur pelaksanaan kegiatan pengabdian kepada masyarakat dalam bentuk asistensi praktikum fisika untuk kelas $\mathrm{X}$ dan fun science project meliputi:

1. Kegiatan Asistensi Praktikum Fisika

Kegaitan asistensi praktikum fisika mengacu pada prosedur Peer Assisance Learning (PAL) seperti dikemukakan oleh (Suryaningsih, 2017); meliputi:
a. Studi pendahuluan
b. Pesiapan dan perancangan kegiatan asistensi di SMA Negeri 9 Purworejo
c. Pembuatan perangkat kegiatan praktikum
d. Pelaksanaan praktikum
e. Evaluasi

2. Kegiatan Fun Science Project
a. Persiapan alat dan bahan
b. Workshop pembuatan roket air dari botol air mineral
c. Pembuatan mekanisme peluncur (louncher)
d. Peluncuran roket air
e. Pengamatan bintik hitam matahari

\section{Teknik Analisis Data}

Selama proses kegiatan asistensi di sekolah berlangsung, selain melakukan kegiatan praktikum dilakukan observasi terhadap kemampuan peserta didik dalam melakukan kerja laboratorium. Sementara itu, mahasiswa yang melaksanakan pendampingan praktikum diobservasi tenteng keterampilan mengajar praktikum. Observasi dilakukan oleh tiga orang observer yaitu dosen pendamping asistensi dengan memberikan skor 1-5 pada lembar observasi kemampuan kerja laboratorium dan keterampilan mengajar praktikum. Skor hasil pengamatan dari masing-masing observer diambil nilai reratanya dan ditentukan nilai 
persentase kemampuan kerja laboratorium dan kemampuan mahasiswa dalam memberikan pendampingan terhadap peserta didik dalam melaksanakan praktikum.

\section{HASIL DAN PEMBAHASAN}

Kegiatan asistensi praktikum fisika dasar merupakan serangkaian kegiatan perkuliahan Asistensi yang memiliki bobot 2 sks yang dibagi menjadi dua sesi yaitu asistensi 1 dan asistensi 2. Kegiatan asistensi mahasiswa sejatinya dilaksnakan di laboratorium pendidiakan Fisika di laboratorium terpadu UM Purworejo. Namun guna memberikan wawasan dan interaktifitas mahasiswa dengan siswa secara langsung, asistensi juga dilaksanakan di sekolah-sekolah dalam bentuk pendampingan praktikum fisika, salah satunya di SMA Negeri 9 Purworejo.

Kegiatan asistensi seperti dipaparkan pada bagian prosedur, mengacu pada langkahlangkah kegiatan PAL,yang meliputi studi pendahuluan, persiapan, pembuatan perangkat, pelaksanaan, dan evaluasi. Kegiatan pendahuluan meliputi analisis kebutuhan terhadap jenis praktikum apa saja yang hendak dilaksanakan di sekolah. Pada tahap ini dilakukan konsultasi terhadap guru Fisika di sekolah serta mengajukan perijinan kegiatan asistensi kepada pihak sekolah. Tahap persiapan dan perancangan kegiatan meliputi persiapan materi, persiapan alat dan bahan, serta persiapan pembagian tugas sesuai dengan topik praktikum yang hendak dilaksanakan. Selain itu, disusun pula panduan percobaan dalam bentuk lembar kegiatan peserta didik sebagai petunjuk percobaan. Tahap ini sekaligus melingkupi tahapan pembuatan perangkat untuk kegiatan praktikum. Tahapan pelaksanaan merupakan pelaksanaan asistensi di SMA Negeri 9 Purworejo. Peserta didik dibagi menjadi 4 kelompok sesuai dengan pos jenis percobaan yang dilakukan yaitu: pengukuran, GLB, GLBB, dan penentuan nilai percepatan gravitasi bumi $(g)$ dengan ayunan matematis. Setiap kelompok melaksanakan keempat jenis praktikum tersebut dengan cara bergiliran (moving groups). Setalah melaksanan percobaan peserta didik membuat laporan sementara terkait data hasil pengamatan yang dilaksanakan, kemudian membuat laporan kegiatan untuk dikumpulkan di pertemuan berikutnya.

Selama pelaksanaan kegiatan asistensi ini, dilakukan observasi terhadap peserta didik terkait penilaian kinerja peserta didik dalam kerja laboratorium. Aspek yang diamati meliputi: (1) kemampuan peserta didik dalam menyiapkan alat dan bahan, (2) kemampuan merangkai alat dan bahan, (3) kemampuan mengkalibrasi alat, (4) kemampuan melakukan percobaan, (5) kemampuan mengambil data percobaan, (6) pengolahan dan analisis data percobaan, (6) kerjasama kelompok, (7) kemampuan menyimpulkan hal percobaan, (8) kemampuan menyusun laporan. Masing-masing aspek penilaian kinerja peserta didik dalam kegiatan asistensi diamati menggunakan lembar observasi keterlaksanaan kegiatan, adapun hasilnya disajikan pada Tabel 1. 
Tabel 1. Hasil penilaian kinerja peserta didik

\begin{tabular}{ccc}
\hline Aspek & Rerata Skor & Persentase \\
\hline Aspek 1 & 4,00 & $80 \%$ \\
Apek 2 & 3,67 & $73 \%$ \\
Aspek 3 & 3,33 & $80 \%$ \\
Aspek 4 & 3,33 & $67 \%$ \\
Aspek 5 & 3,33 & $67 \%$ \\
Aspek 6 & 3,67 & $73 \%$ \\
Aspek 7 & 3,67 & $73 \%$ \\
\hline
\end{tabular}

Tabel 1 tentang menyajikan capaian kemampuan peserta didik dalam melakukan kerja laboratorium. Aspek 1 adalah kemampuan peserta didik dalam menyiapkan alat dan bahan yang memperoleh skor rerata 40,00 atau 80\%. Hasil ini menunjukkan bahwa sebagian peserta didik cukup antusias dalam mempersiapkan alat dan bahan praktikum. Aspek kedua adalah merangkai alat dan bahan memperoleh skor rerata 3,67 atau 73\%. Hasil ini termasuk kategori cukup baik mengingat sebagian peserta didik belum mengerti tentang alat dan bahan yang digunakan, sehingga mennggu arahan dari tim asistensi untuk menggunakan alat yang telah disediakan. Hal tersebut turut berpengaruh pada aspek kelima dan keenam, masing-masing memperoleh skor rerata 3,33 dengan persentase $67 \%$, pada kategori cukup. Sementara itu untuk aspek kerjasama dan penyusunan laporan diperoleh rerata capaian sebesar 3,67 atau $73 \%$ dalam kategori baik. Adapun kegiatan Fun Science berupa peluncuran roket dan pengamatan bintik hitam matahari menggunakan teleskop tidak dilakukan observasi baik untuk peserta didik maupun mahasiswa yang mengikuti asistensi. Observasi terhadap mahasiswa program studi pendidikan fisika yang melaksankan kegiatan asistensi mencakup penilaian (1) kreativitas dalam mengampu praktikum, (2) penguasaan alat dan bahan, (3) kemampuan berkomunikasi ilmiah, (4) kemampuan kerjasama, dan (5) kemampuan mengajar. Adapun hasil penilaian terhadap kompetensi mahasiswa dalam melaksnakan asistensi disajikan pada Gambar 2.

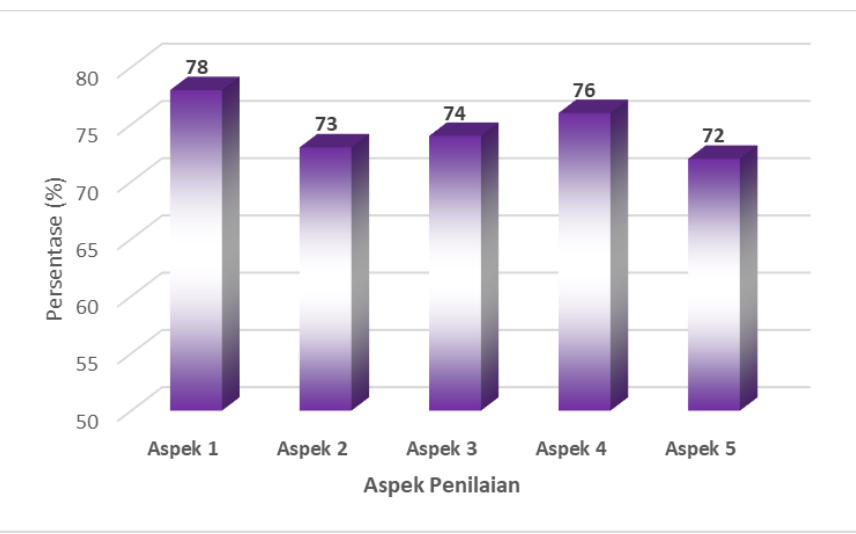

Gambar 2. Hasil penilaian terhadap mahasiswa

Berdasarkan hasil penilaian melalui observasi terhadap kemampuan mahasiswa dalam melaksanakan asistensi seperti pada Gambar 2, aspek pertama terkait kreativitas dalam mengampu praktikum memperoleh persentase tertinggi yaitu sebesar 78\%, hal ini mengindikasikan bahwa mahasiswa dengan keterbatasan alat percobaan yang ada dapat 
mencari solusi alternatif jika menemui kendala teknis sehingga percobaan dapat dilaksanakan. Aspek kedua terkait alat dan bahan memiliki skor yang relatif rendah. Penguasaan alat yang dimaksud adalah mekanisme kalibrasi alat peraga, hampir semua mahasiswa tidak melakukan kalibrasi sebelum alat digunakan untuk kegiatan percobaan. Aspek kelima juga paling relatif rendah jika dibandingkan dengan aspek pertama hingga keempat, yaitu aspek kemampuan mengajar. Hal tersebut disebabkan karena tida semua aspek penilaian dalam proses pembelajaran tidak dapat teramati dengan baik, karena mahasiswa fokus pada kegiatan praktikum. Hasil pengamatan ini sejalan dengan (Suwardi, 2016) yang mengemukakan bahwa kegiatan asistensi perlu ditinjau kembali aspek efektivitasnya. Hal ini didukung kajian oleh (Marwoto, 2010; Wahyuningsih dkk., 2019) tentang proses perkuliahan yang didukung kegiatan asistensi.

Setelah mengikuti serangkaian proses kegiatan praktikum, pada hari kedua peserta didik melakukan kegiatan fun science berupa workshop perancangan roket air dan pengamatan bintik hitam matahari (sun spot) di laboratorium dan halaman SMA Negeri 9 Purworejo.

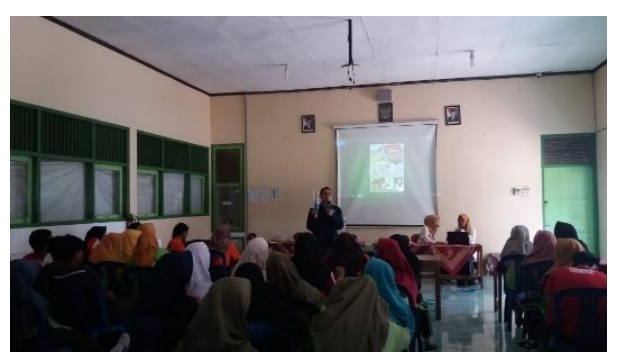

(a)

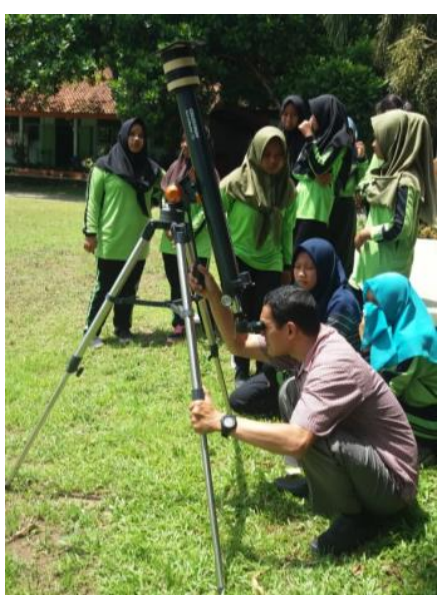

(b)

Gambar 3. Dokumentasi kegiatan, (a) workshop roket air, (b) pengamatan sun spot

Kegiatan akhir dari seluruh rangkaian kegiatan asistensi dan fun science di SMA Negeri 9 Purworejo adalah evaluasi. Evaluasi dilaksankan oleh tim asistensi berserta dosen pendamping, dan dilaporkan kepada kepala SMA Negeri 9 Purworejo. Hasil kegiatan asistensi dan fun science ini disambut baik oleh peserta didik yang ditandai dengan pemahaman konsep, pemahaman analisis data percobaan, dan pengamatan fenomena alam.

\section{KESIMPULAN}

Berdasarkan kegiatan yang telah dilaksankaan apabila ditinjau dari sisi peserta didik, kegiatan asistensi praktikum fisika dasar dapat meningkatkan pemahaman peserta didik serta keterampilan kinerja dalam praktikum fisika. Melalui serangkaian kegaitan dan pendampingan praktikum oleh mahasiswa, kemampuan penguasaan alat percobaan dan 
kemampuan melakukan analisis data peserta didik meningkat. Seiring dengan hal tersebut, dari sisi mahasiswa, kegiatan asistensi turut meningkatkan kemampuan mahasiswa dalam melaksanakan kegiatan praktikum fisika, penguasaan konsep dan penggunaan alat, maupun penguasaan kelas sebagai bentuk penerapan kemampuan pedagogis mahasiswa, meskipun pada beberapa aspek perlu ditingkatkan. Untuk kegiatan selanjutnya, asistensi dapat dilaksanakan pada materi liannya dan disekolah yang lainnya. Untuk kajian selanjutnya dapat dilakukan kajian tentang efektivitas asistensi terhadap indikator-indikator lain yang turut mempengaruhi keberhasilan belajar peserta didik dalam pembelajaran fisika di sekolah.

\section{DAFTAR PUSTAKA}

Fidiana, L., Subali, B., \& Dwijananti, P. (2012). Pembuatan dan implementasi modul praktikum fisika berbasis masalah untuk meningkatkan kemandirian belajar siswa kelas XI. UPEJ Unnes Physics Education Journal, 1(2).

Irwanto, P. D. (2016). Pengaruh Gaya Mengajar Dosen, Asistensi dan Fasilitas Belajar Terhadap Prestasi Belajar Aplikasi Akuntansi Pemeriksaan. Jurnal Akuntansi dan Sistem Teknologi Informasi, 11(2).

Kurnianto, P., \& Dwijanant, P. (2010). Pengembangan Kemampuan Menyimpulkan dan Mengkomunikasikan Konsep Fisika Melalui Kegiatan Praktikum Fisika Sederhana. Jurnal Pendidikan Fisika Indonesia, 6(1).

Kurniawan, E. S., \& Ngazizah, N. (2017). IbM Peningkatan Keterampilan Guru SD Muhammadiyah Se Kabupaten Purworjeo Dalam Pengelolaan Laboratorium dan Pengembangan Alat Peraga IPA Terbarukan. Surya Abdimas, 1(1), 1-5.

Marwoto, P. (2010). Peningkatan Kualitas Perkuliahan Solusi Deret Melalui Pendekatan Teaching Assistant. Jurnal Pendidikan Fisika Indonesia, 6(1).

Rahayu, G. D. S., \& Firmansyah, D. (2019). Pengembangan pembelajaran inovatif berbasis pendampingan bagi guru sekolah dasar. Abdimas Siliwangi, 1(1), 17-25.

Rahayu, P., Mulyani, S., \& Miswadi, S. (2012). Pengembangan pembelajaran IPA terpadu dengan menggunakan model pembelajaran problem base melalui lesson study. Jurnal Pendidikan IPA Indonesia, 1(1).

Rediarta, I. W., Sudarma, I. K., \& Murda, I. N. (2014). Pengaruh Model Kooperatif Two Stay Two Stray Terhadap Hasil Belajar IPA. MIMBAR PGSD Undiksha, 2(1).

Sudargo, F. (2010). Kemampuan pedagogik calon guru dalam meningkatkan kemampuan berpikir kritis dan keterampilan proses siswa melalui pembelajaran berbasis praktikum. Jurnal Pengajaran MIPA, 15(1), 4-12.

Suryaningsih, Y. (2017). Pembelajaran berbasis praktikum sebagai sarana siswa untuk berlatih menerapkan keterampilan proses sains dalam materi biologi. BIO EDUCATIO:(The Journal of Science and Biology Education), 2(2).

Suwardi, S. (2016). Efektivitas Pelatihan Asisten Praktikum dalam Meningkatkan Kompetensi Asisten untuk Membimbing Praktikum Fisika Dasar I. Jurnal Pendidikan Eksakta, 1(1).

Wahyuningsih, F. T., Al Hakim, Y., \& Ashari, A. (2019). Pengembangan Alat Peraga Pengukur Debit Air Menggunakan Sensor Flow Berbasis Arduino Sebagai Media Pembelajaran Fluida. Radiasi: Jurnal Berkala Pendidikan Fisika, 12(1), 38-45. 
Wattimena, H., Suhandi, A., \& Setiawan, A. (2014). Pengembangan Perangkat Perkuliahan Eksperimen Fisika untuk Meningkatkan Kreativitas Mahasiswa Calon Guru dalam Mendesain Kegiatan Praktikum Fisika di SMA. Jurnal Pendidikan Fisika Indonesia, 10(2), $128-139$. 